\title{
Chlorination of Conjugated Side Chains to Enhance Intermolecular Interactions for Elevated Solar Conversion
}

Pengjie Chao ${ }^{\dagger}$, Hui Chen ${ }^{\ddagger}, \|$, Yulin Zhu*, Nan Zheng», Hong Meng ${ }^{\dagger}$ and Feng He ${ }^{\ddagger}, *$

†School of Advanced Materials, Peking University Shenzhen Graduate School, Peking University, Shenzhen, 518055, China

\Shenzhen Grubbs Institute and Department of Chemistry, Southern University of Science and Technology, Shenzhen, 518055, China

"Academy for Advanced Interdisciplinary Studies and Department of chemistry, South ern University of Science and Technology, Shenzhen 518055, China

$\S$ Institute of Polymer Optoelectronic Materials and Devices, State Key Laboratory of Luminescent Materials and Devices, South China University of Technology, Guangzhou 510640, China.

\section{Corresponding Author}

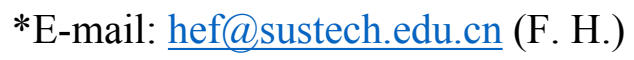

\section{Experimental Section}

Measurements: ${ }^{1} \mathrm{H}$ NMR and ${ }^{13} \mathrm{C}$ NMR spectra were recorded on Bruker Avance400/500 spectrometers. Mass spectra (high resolution mass spectrometer (HRMS)) were determined on a Bruker Bruker Avance-400/600 spectrometer. Gel permeation chromatography (GPC) was performed on Agilent Technologies 1260 infinity II high temperature GPC system using 1,2,4-trichlorobenzene (TCB) as eluent at $150{ }^{\circ} \mathrm{C}$. Solution and thin film optical absorption spectra were measured with a UV-Vis 
spectrophotometer (Shimadzu, UV3600). The thin films of the polymers were spincoated from their solutions in chloroform, and then the film absorption spectra were measured. The electrochemical cyclic voltammetry $(\mathrm{CV})$ was carried out on a $\mathrm{CHI}$ 660E Electrochemicacl Workstation (Shanghai Chenhua Instrumental Co., Ltd. China), with glassy carbon disk, $\mathrm{Pt}$ wire and $\mathrm{Ag} / \mathrm{Ag}+$ electrode as working electrode, counter electrode and reference electrode in an acetonitrile solution of $0.1 \mathrm{~mol} \mathrm{~L}^{-1}$ Tetrabutylammonium phosphorus hexafluoride $\left(n-\mathrm{Bu}_{4} \mathrm{NPF}_{6}\right)$ at a potential scan rate of $100 \mathrm{mV} \mathrm{s}^{-1}$ under a argon atmosphere. Tapping mode atom force microscopy (TM-AFM) images were taken on a NanoScope IIIa controller (Veeco Metrology Group/Digital Instruments, Sant a Barbara, CA), using built-in software (version V6.13R1) to capture images. Transmission electron microscopy (TEM) images were acquired using a HITACHI H-7650 electron microscope operating at an acceleration voltage of $100 \mathrm{kV}$. The thickness of the blend films was determined by a Dektak $6 \mathrm{M}$ surface profilometer. All $J-V$ curves were captured under an AAA solar simulator (SAN-EI) calibrated by a standard single-crystal Si photovoltaic cell (certificated by National Institute of Metrology).

\section{Device Fabrication and Testing}

The inverted device structure was $\mathrm{ITO} / \mathrm{ZnO} /$ polymer: $\mathrm{Y} 6 / \mathrm{MoO}_{3} / \mathrm{Ag}$. ITO-coated glass substrates were cleaned with deionized water, acetone and isopropyl alcohol for 30 minutes once time and dried in the drying oven at $80^{\circ} \mathrm{C}$ for $12 \mathrm{~h}$ before used. The ITO glass was then placed in the UV-ozone for 15 minutes and the sol-gel-derived $\mathrm{ZnO}$ films was spin-coated onto the ITO sustrated followed by thermal treatment at $200{ }^{\circ} \mathrm{C}$ for $30 \mathrm{~min}$ and cooled to room temperature under vacuum. The mixture of polymer/Y6 (1:1.2 by wt/wt ratio) was dissolved in chloroform to obtain $10 \mathrm{mg} \mathrm{mL}^{-1}$ of solution. The blend was stirred in the glove box for overnight. The active layer was spin-coating at $1500 \mathrm{rpm}$ for $60 \mathrm{~s}$ to get the blend film. A $10 \mathrm{~nm} \mathrm{MoO}$ layer and a $100 \mathrm{~nm} \mathrm{Ag}$ layer were subsequently evaporated through a shadow mask to define the active area of the devices. The power conversion efficiencies (PCEs) were tested under AM 1.5G 
irradiation with the intensity of $100 \mathrm{~mW} \mathrm{~cm}^{-2}$ (Enlitech.Inc) which was calibrated by a NREL certified standard silicon cell $\left(4 \mathrm{~cm}^{-2}\right)$. The $J-V$ curves were recorded with the computer-controlled Keithley 2400 sourcemeter in a dry box under an inert atmosphere. The external quantum efficiency (EQE) spectra were measured through the measurement of solar cell spectral response measurement system QE-R3011 (Enli Technology Ltd., Taiwan).

The hole mobility of the photosensitive layers was measured by the space charge limited current (SCLC) method using hole-only device with the structure of ITO/PEDOT:PSS/polymer:Y6 (1:1, wt/wt) $/ \mathrm{MoO}_{3} / \mathrm{Ag}$. The processing conditions used for the active layers were the optimized ones. Charge mobility was extracted by fitting the current density-voltage curves, recorded under dark conditions, with the MottGurney equation. The mobility was determined by fitting the dark current to the model of a single carrier SCLC, which is described by the equation

$$
J=\frac{9}{8} \varepsilon_{0} \varepsilon_{r} \mu_{h} \frac{V^{2}}{d^{3}}
$$

where $J$ is the current, $\mu_{\mathrm{h}}$ is the zero-field mobility, $\varepsilon_{0}$ is the permittivity of free space, $\varepsilon_{\mathrm{r}}$ is the relative permittivity of the material, $d$ is the thickness of the active layer, and $V$ is the effective voltage. The effective voltage can be obtained by subtracting the builtin voltage $\left(V_{\mathrm{bi}}\right)$ and the voltage drop $\left(V_{\mathrm{s}}\right)$ from the substrate's series resistance from the applied voltage $\left(V_{\mathrm{appl}}\right), V=V_{\mathrm{appl}}-V_{\mathrm{bi}}-V_{\mathrm{s}}$. The hole-mobility can be calculated from the slope of the $J^{1 / 2} \sim V$ curves.

\section{Materials}

All chemicals and solvents were reagent grades and purchased from Aldrich, Energy, Derthon and solarmer, respectively. All starting reagents were obtained commercially as analytical grade and used directly without any purification unless stated otherwise. Toluene and THF were distilled over sodium/benzophenone and calcium hydride under $\mathrm{N}_{2}$ prior to use. 


\section{Synthesis and characterization}
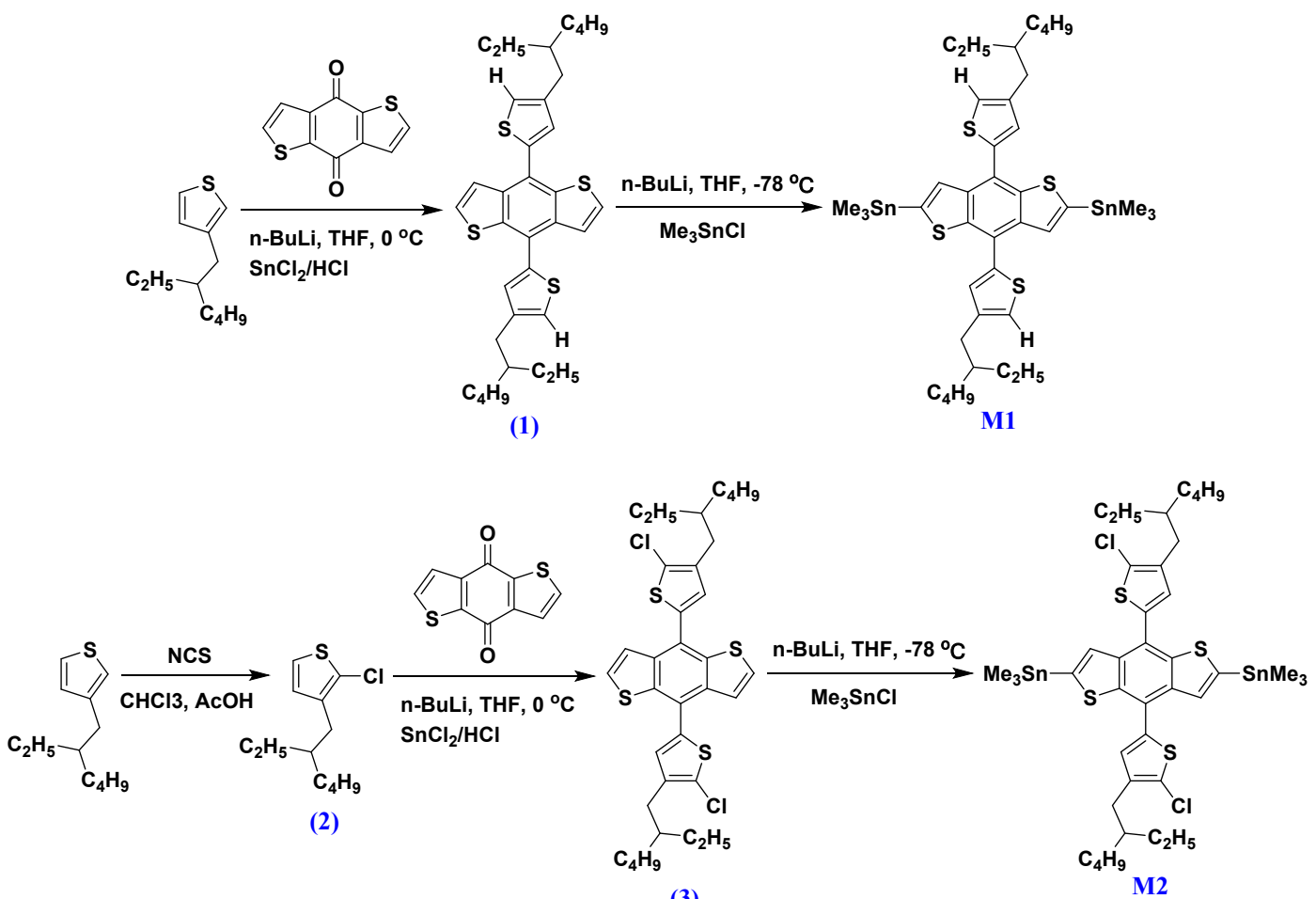

(3)
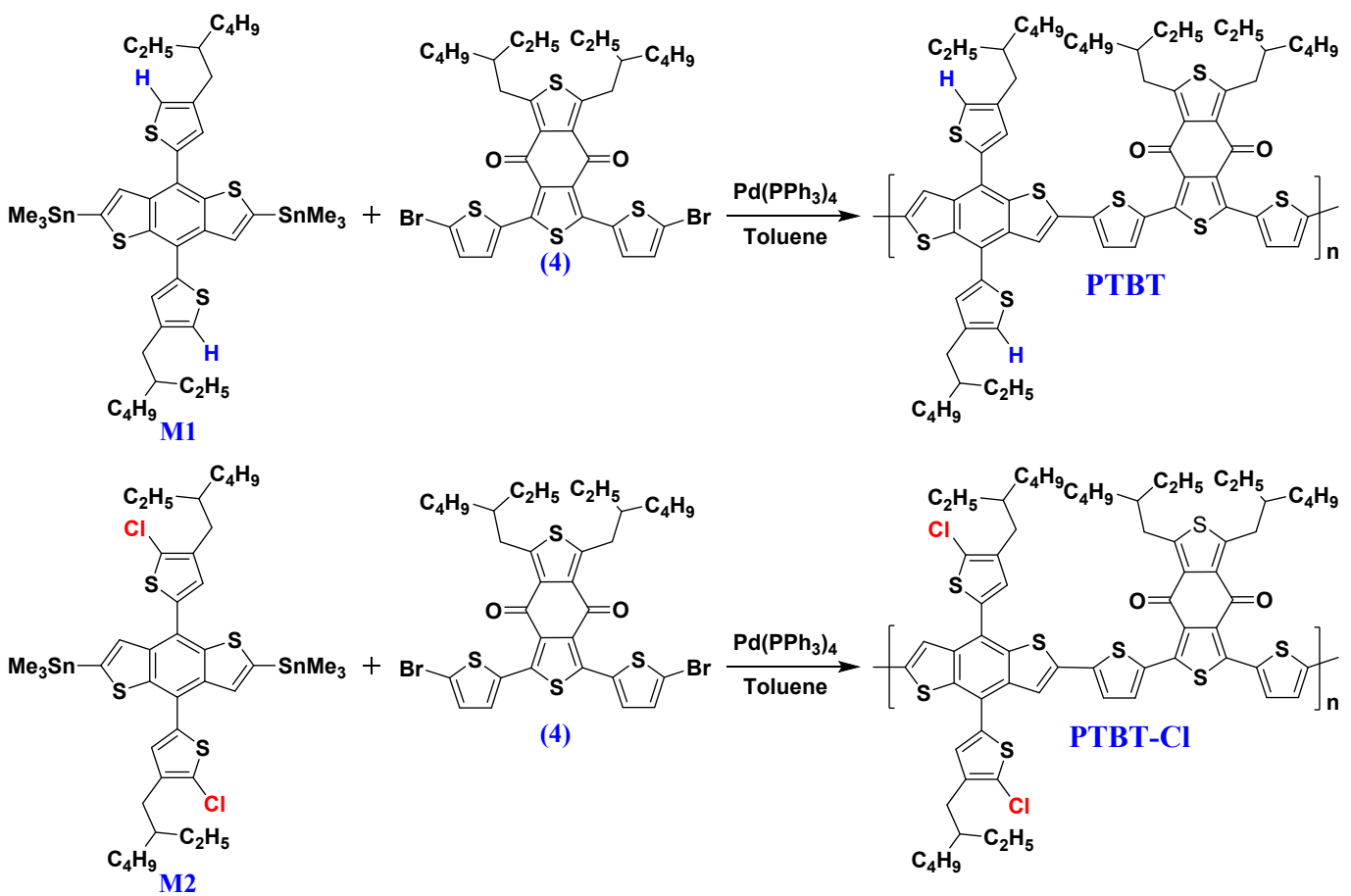

Scheme S1. Synthetic routes of monomers M1 and M2, and polymers PTBT and PTBT-Cl.

\section{4,8-bis(4-(2-ethylhexyl)thiophen-2-yl)benzo[1,2-b:4,5-b']dithiophene (1)}

Under protection of argon, $n-\mathrm{BuLi}(23.34 \mathrm{ml}, 2.4 \mathrm{M}, 56.02 \mathrm{mmol})$ was slowly added to 
compound 3-(2-ethylhexyl)thiophene $(10.00 \mathrm{~g}, 50.93 \mathrm{mmol})$ in THF $(200 \mathrm{ml})$ at $0{ }^{\circ} \mathrm{C}$, and the mixture was kept at $0{ }^{\circ} \mathrm{C}$ for $1 \mathrm{~h}$ and heated for $2 \mathrm{~h}$ at $50{ }^{\circ} \mathrm{C}$. Then benzo[1,2$\mathrm{b}: 4,5-\mathrm{b}^{\prime}$ ]dithiophene-4,8-dione $(3.74 \mathrm{~g}, 16.98 \mathrm{mmol})$ was added quickly, and the mixture stirred for $2 \mathrm{~h}$ at $50{ }^{\circ} \mathrm{C}$. After cooling down to the room temperature, $\mathrm{SnCl}_{2} \cdot 2 \mathrm{H}_{2} \mathrm{O}(22.81 \mathrm{~g}, 101.10 \mathrm{mmol})$ in $10 \% \mathrm{HCl}(50 \mathrm{ml})$ was added and the mixture was stirred overnight at $50^{\circ} \mathrm{C}$. The mixture was cooled down to room temperature and poured into the ice water. Then the mixture was extracted by ethyl acetate. The organic phase was dried over anhydrous sodium sulfate and concentrated by a rotary evaporator. Further purification was carried out by column chromatography using petroleum ether as eluent to obtain the production as a yellow sticky oil (3.63 g, 36.93\%). ${ }^{1} \mathrm{H}$ NMR (400 MHz, chloroform- $d$ ) $\delta 7.62(\mathrm{~d}, J=5.7 \mathrm{~Hz}, 2 \mathrm{H}), 7.45(\mathrm{~d}, J=5.7 \mathrm{~Hz}, 2 \mathrm{H}), 7.29(\mathrm{~s}, 2 \mathrm{H})$, $7.08(\mathrm{~s}, 2 \mathrm{H}), 2.65(\mathrm{~d}, J=6.8 \mathrm{~Hz}, 4 \mathrm{H}), 1.71-1.59(\mathrm{~m}, 2 \mathrm{H}), 1.49-1.17(\mathrm{~m}, 16 \mathrm{H}), 0.99$ $-0.84(\mathrm{~m}, 12 \mathrm{H}) .{ }^{13} \mathrm{C}$ NMR (101 MHz, chloroform- $d$ ) $\delta 142.26,139.07,139.05,136.49$, $129.93,127.60,124.12,123.29,121.86,40.51,34.56,32.63,29.01,25.78,23.09,14.19$, 10.96. HRMS (MALDI ${ }^{+}$): calculated for $\mathrm{C}_{34} \mathrm{H}_{42} \mathrm{~S}_{4}\left[\mathrm{M}^{+}\right]: 578.2169$; Found: 578.3626 .

\section{(4,8-bis(4-(2-ethylhexyl)thiophen-2-yl)benzo[1,2-b:4,5-b']dithiophene-2,6-}

\section{diyl)bis(trimethylstannane) (M1)}

To a solution of compound $1(3.60 \mathrm{~g}, 6.22 \mathrm{mmol})$ in THF $(100 \mathrm{ml})$ at $-78^{\circ} \mathrm{C}$ was slowly added $n$-BuLi $(5.70 \mathrm{ml}, 2.4 \mathrm{M}, 13.68 \mathrm{mmol})$. After the addition, the mixture was kept at $-78^{\circ} \mathrm{C}$ for $4 \mathrm{~h}$, trimethyltin chloride solution in THF $(14.3 \mathrm{ml}, 1.0 \mathrm{M})$ was added at -78 ${ }^{\circ} \mathrm{C}$. The solution was warmed naturally to room temperature and quenched with $50 \mathrm{ml}$ of water and $200 \mathrm{ml}$ of ether was added, the mixture was washed with ultrapure water 
ten times. After drying over $\mathrm{Na}_{2} \mathrm{SO}_{4}$, the solvent was removed and the residue was recrystallized from isopropyl alcohol to afford the yellow crystal (4.38 g, 77.94\%).

${ }^{1} \mathrm{H}$ NMR (400 MHz, chloroform-d) $\delta 7.67$ (s, 2H), $7.31(\mathrm{~s}, 2 \mathrm{H}), 7.08$ (s, 2H), 2.67 (d, J $=6.7 \mathrm{~Hz}, 4 \mathrm{H}), 1.66(\mathrm{q}, J=5.7,5.3 \mathrm{~Hz}, 2 \mathrm{H}), 1.45-1.26(\mathrm{~m}, 16 \mathrm{H}), 0.99-0.83(\mathrm{~m}, 12 \mathrm{H})$, 0.39 (s, 18H). ${ }^{13} \mathrm{C}$ NMR (101 MHz, chloroform- $d$ ) $\delta 143.37,142.53,142.20,139.81$, 137.36, 131.07, 129.96, 122.50, 121.64, 40.63, 34.63, 32.68, 29.11, 25.84, 23.14, 14.26, 11.07, -8.35. HRMS (MALDI ${ }^{+}$): calculated for $\mathrm{C}_{40} \mathrm{H}_{58} \mathrm{~S}_{4} \mathrm{Sn}_{2}\left[\mathrm{M}^{+}\right]: 904.5640$; Found: 904.3618.

\section{2-Chloro-3-(2-ethylhexyl)thiophene (2).}

To a solution of 3-(2-ethylhexyl)thiophene $(23.35 \mathrm{~g}, 118.9 \mathrm{mmol})$ in $300 \mathrm{~mL}$ of $\mathrm{AcOH} / \mathrm{CHCl}_{3}(1: 1)$ was added $\mathrm{N}$-chlorosuccinimide (NCS) $(15.88 \mathrm{~g}, 118.9 \mathrm{mmol})$ in one portion under nitrogen protection in ice bath, and the reaction mixture was kept stirring overnight. Then water was added into the mixture, the mixture was extracted with hexane, and the organic layer was washed with brine and dried over anhydrous sodium sulfate. Removal of the solvent and column purification on silica gel using hexane as eluent, the residue was further purified through reduced pressure distillation to obtain a colorless oil (25.62 g, 93.37\%). ${ }^{1} \mathrm{H}$ NMR (400 MHz, chloroform- $d$ ) $\delta 7.02$ $(\mathrm{d}, J=5.7 \mathrm{~Hz}, 1 \mathrm{H}), 6.76(\mathrm{~d}, J=5.7 \mathrm{~Hz}, 1 \mathrm{H}), 2.50(\mathrm{~d}, J=7.1 \mathrm{~Hz}, 2 \mathrm{H}), 1.65-1.56(\mathrm{~m}$, 1H), $1.28(\mathrm{~m}, 8 \mathrm{H}), 0.88(\mathrm{t}, J=7.3 \mathrm{~Hz}, 6 \mathrm{H}) .{ }^{13} \mathrm{C}$ NMR (101 MHz, chloroform- $\left.d\right) \delta$ $138.37,128.45,124.95,121.80,39.93,32.47,32.14,28.78,25.66,23.03,14.12,10.79$. GC-MS: calculated for $\mathrm{C}_{12} \mathrm{H}_{19} \mathrm{ClS}\left[\mathrm{M}^{+}\right]: 230.8$; Found: 230.1 .

4,8-bis(5-chloro-4-(2-ethylhexyl)thiophen-2-yl)benzo[1,2-b:4,5-b']dithiophene (3) 
Under protection of argon, $n$ - BuLi $(23.47 \mathrm{ml}, 2.4 \mathrm{M}, 56.33 \mathrm{mmol})$ was slowly added to compound $2(10.00 \mathrm{~g}, 43.33 \mathrm{mmol})$ in THF $(150 \mathrm{ml})$ at $0{ }^{\circ} \mathrm{C}$, and the mixture was kept at $0{ }^{\circ} \mathrm{C}$ for $1 \mathrm{~h}$ and heated for $2 \mathrm{~h}$ at $50{ }^{\circ} \mathrm{C}$. Then benzo[1,2-b:4,5-b']dithiophene-4,8dione (3.18 g, $14.44 \mathrm{mmol})$ was added quickly, and the mixture stirred for $2 \mathrm{~h}$ at $50^{\circ} \mathrm{C}$. After cooling down to the room temperature, $\mathrm{SnCl}_{2} \cdot 2 \mathrm{H}_{2} \mathrm{O}(22.81 \mathrm{~g}, 101.10 \mathrm{mmol})$ in $10 \%$ $\mathrm{HCl}(50 \mathrm{ml})$ was added and the mixture was stirred overnight at $50^{\circ} \mathrm{C}$. The mixture was cooled down to room temperature and poured into the ice water. Then the mixture was extracted by ethyl acetate. The organic phase was dried over anhydrous sodium sulfate and concentrated by a rotary evaporator. Further purification was carried out by column chromatography using petroleum ether as eluent to obtain the production as a yellow sticky oil (7.92 g, 84.71\%). ${ }^{1} \mathrm{H}$ NMR (400 MHz, chloroform- $d$ ) $\delta 7.59(\mathrm{~d}, J=5.7 \mathrm{~Hz}$, 2H), $7.47(\mathrm{~d}, J=5.7 \mathrm{~Hz}, 2 \mathrm{H}), 7.14(\mathrm{~s}, 2 \mathrm{H}), 2.61(\mathrm{~d}, J=7.1 \mathrm{~Hz}, 4 \mathrm{H}), 1.69(\mathrm{~m}, 2 \mathrm{H}), 1.46$ $-1.25(\mathrm{~m}, 16 \mathrm{H}), 0.98-0.84(\mathrm{~m}, 12 \mathrm{H}) .{ }^{13} \mathrm{C}$ NMR (101 MHz, chloroform- $\left.d\right) \delta 139.18$, $138.97,136.56,135.65,129.46,128.08,126.03,123.38,123.02,40.00,32.68,32.38$, 28.94, 25.88, 23.13, 14.21, 10.92. HRMS $\left(\mathrm{MALDI}^{+}\right)$: calculated for $\mathrm{C}_{34} \mathrm{H}_{40} \mathrm{Cl}_{2} \mathrm{~S}_{4}$ $\left[\mathrm{M}^{+}\right]: 647.8340$; Found: 648.1123 .

\section{(4,8-bis(5-chloro-4-(2-ethylhexyl)thiophen-2-yl)benzo[1,2-b:4,5-b']dithiophene-}

\section{2,6-diyl)bis(trimethylstannane) (M2)}

To a solution of compound $3(8.00 \mathrm{~g}, 12.35 \mathrm{mmol})$ in $\mathrm{THF}(300 \mathrm{ml})$ at $-78{ }^{\circ} \mathrm{C}$ was slowly added $n$-BuLi $(12.35 \mathrm{ml}, 2.4 \mathrm{M}, 29.64 \mathrm{mmol})$. After the addition, the mixture was kept at $-78^{\circ} \mathrm{C}$ for $4 \mathrm{~h}$, trimethyltin chloride solution in THF $(32.11 \mathrm{ml}, 1.0 \mathrm{M})$ was added at $-78^{\circ} \mathrm{C}$. The solution was warmed naturally to room temperature and quenched 
with $50 \mathrm{ml}$ of water and $200 \mathrm{ml}$ of ether was added, the mixture was washed with ultrapure water ten times. After drying over $\mathrm{Na}_{2} \mathrm{SO}_{4}$, the solvent was removed and the residue was recrystallized from isopropyl alcohol to afford the yellow crystal (8.93g, $74.29 \%)$.

${ }^{1} \mathrm{H}$ NMR (400 MHz, chloroform-d) $\delta 7.63(\mathrm{~s}, 2 \mathrm{H}), 7.16(\mathrm{~s}, 2 \mathrm{H}), 2.63(\mathrm{~d}, J=7.1 \mathrm{~Hz}$, 4H), $1.71(\mathrm{~m}, 2 \mathrm{H}), 1.51-1.28(\mathrm{~m}, 16 \mathrm{H}), 1.02-0.83(\mathrm{~m}, 12 \mathrm{H}), 0.41(\mathrm{~s}, 18 \mathrm{H}) .{ }^{13} \mathrm{C}$ NMR $(101 \mathrm{MHz}$, chloroform- $d$ ) $\delta 143.39,143.26,138.79,137.33,136.30,130.57,129.38$ 125.61, 121.62, 39.94, 32.64, 32.37, 28.94, 25.85, 23.10, 14.21, 10.93, -8.33. HRMS: calculated for $\mathrm{C}_{40} \mathrm{H}_{56} \mathrm{Cl}_{2} \mathrm{~S}_{4} \mathrm{Sn}_{2}\left[\mathrm{MALDI}^{+}\right]$:974.0647; Found: 973.7891 .

Polymerization of PTBT. To a $25 \mathrm{~mL}$ flask, compound M1 (190.44 mg, 0.1956 mmol), compound 4 (150.00 mg, $0.1956 \mathrm{mmol})$ and $\mathrm{Pd}\left(\mathrm{PPh}_{3}\right)_{4}(9.04 \mathrm{mg}, 0.0078 \mathrm{mmol})$ were added under argon, then the reaction container was purged with argon for $20 \mathrm{~min}$ to remove $\mathrm{O}_{2}$. After the addition of toluene $(8 \mathrm{~mL})$, the reactant mixture was heated to reflux and maintained at the same temperature for $18 \mathrm{~h}$. After cooling to room temperature, the mixture was poured into methanol $(200 \mathrm{ml})$, then filtered through a Soxhlet thimble, which was then subjected to Soxhlet extraction with methanol, acetone, hexane and chloroform. The polymer was recovered as solid from the chloroform fraction by precipitation from methanol. The solid was dried under vacuum. Yield: $230.30 \mathrm{mg}(91.81 \%)$. The polymer was thermally stable up to $337^{\circ} \mathrm{C}(5 \%$ weight loss by TGA). GPC: $M_{\mathrm{w}}=64.91 \mathrm{kDa} ; M_{\mathrm{n}}=31.02 \mathrm{kDa}$; PDI=2.09. ${ }^{1} \mathrm{H}$ NMR $(400 \mathrm{MHz}$, $\left.\mathrm{CDCl}_{2} \mathrm{CDCl}_{2}, 100{ }^{\circ} \mathrm{C}\right) \delta(\mathrm{ppm})$ 7.67-7.07 (br, ArH), 3.27-3.21 (br, $\left.\mathrm{Ar}-\mathrm{CH}_{2}\right), 2.65$ (br, Ar- $\left.\mathrm{CH}_{2}\right), 1.71-1.64$ (br, $\left.-\mathrm{CH}\right), 1.32-1.24\left(\mathrm{br},-\mathrm{CH}_{2}\right), 0.88-0.80$ (br, $-\mathrm{CH}_{3}$ ). 
Polymerization of PTBT-CI. PTBT-CI was prepared using the same procedure as PTBT. Yield: $150.10 \mathrm{mg}(66.21 \%)$. GPC: $M_{\mathrm{w}}=84.70 \mathrm{kDa} ; M_{\mathrm{n}}=38.62 \mathrm{kDa}$; PDI=2.19. The polymer was thermally stable up to $377{ }^{\circ} \mathrm{C}\left(5 \%\right.$ weight loss by TGA). ${ }^{1} \mathrm{H}$ NMR $\left(400 \mathrm{MHz}, \mathrm{CDCl}_{2} \mathrm{CDCl}_{2}, 100{ }^{\circ} \mathrm{C}\right) \delta(\mathrm{ppm}) 7.09$ (br, $\left.\mathrm{ArH}\right), 3.28-3.19$ (br, $\left.\mathrm{Ar}-\mathrm{CH}_{2}\right), 2.62$ (br, $\left.\mathrm{Ar}-\mathrm{CH}_{2}\right), 1.69$ (br, -CH), 1.32 (br, $\left.-\mathrm{CH}_{2}\right), 0.92-0.80$ (br, $-\mathrm{CH}_{3}$ ). 


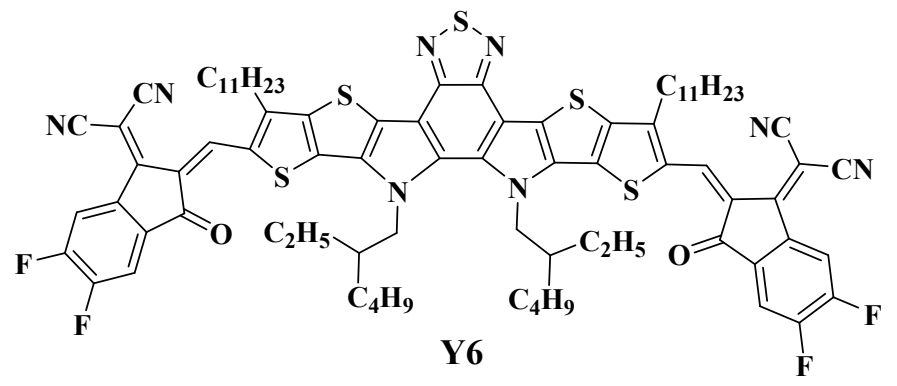

Figure S1. Structure of Y6.
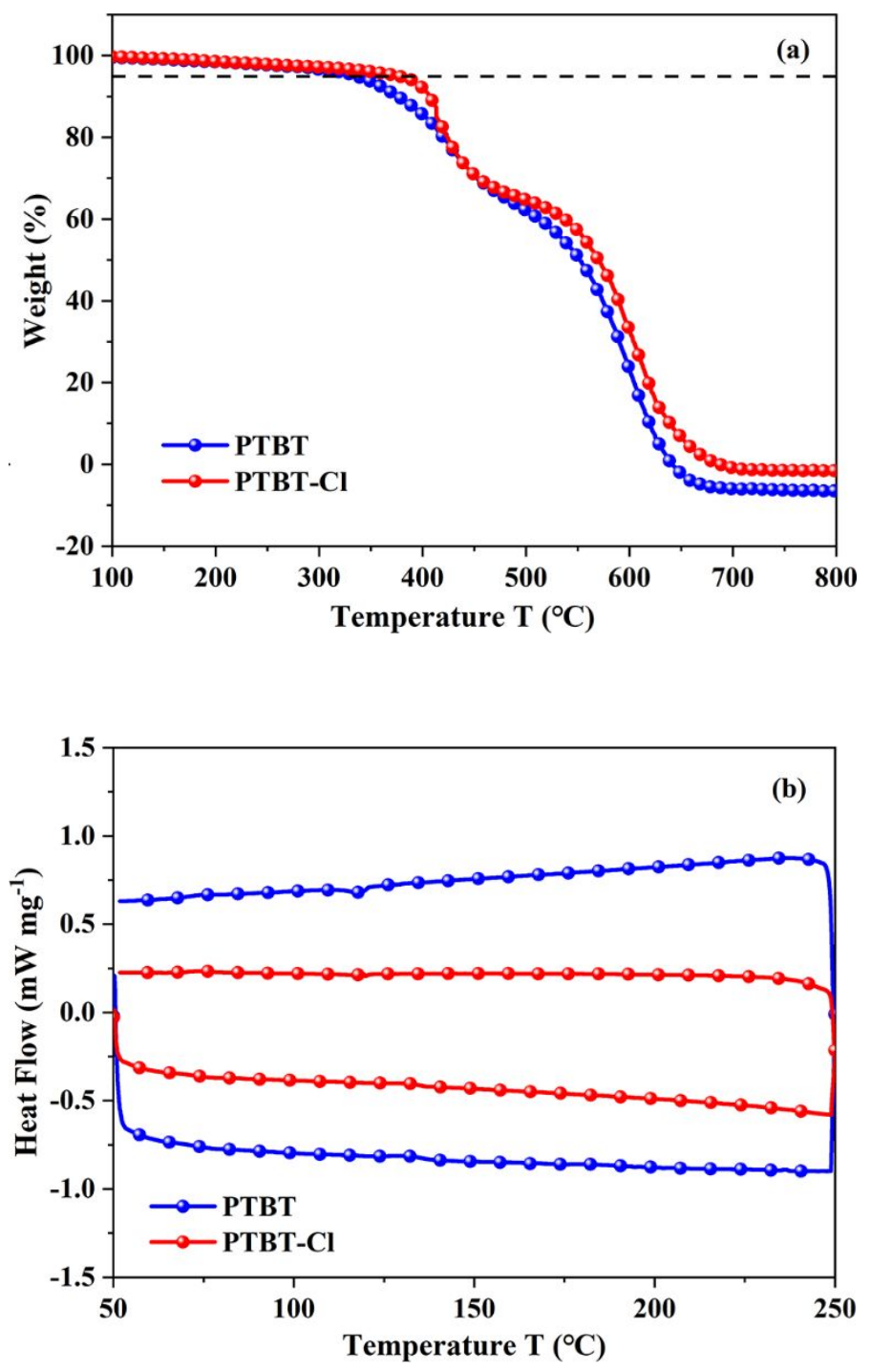

Figure S2. (a) TGA curves and (b) DSC curves of PTBT and PTBT-Cl. 

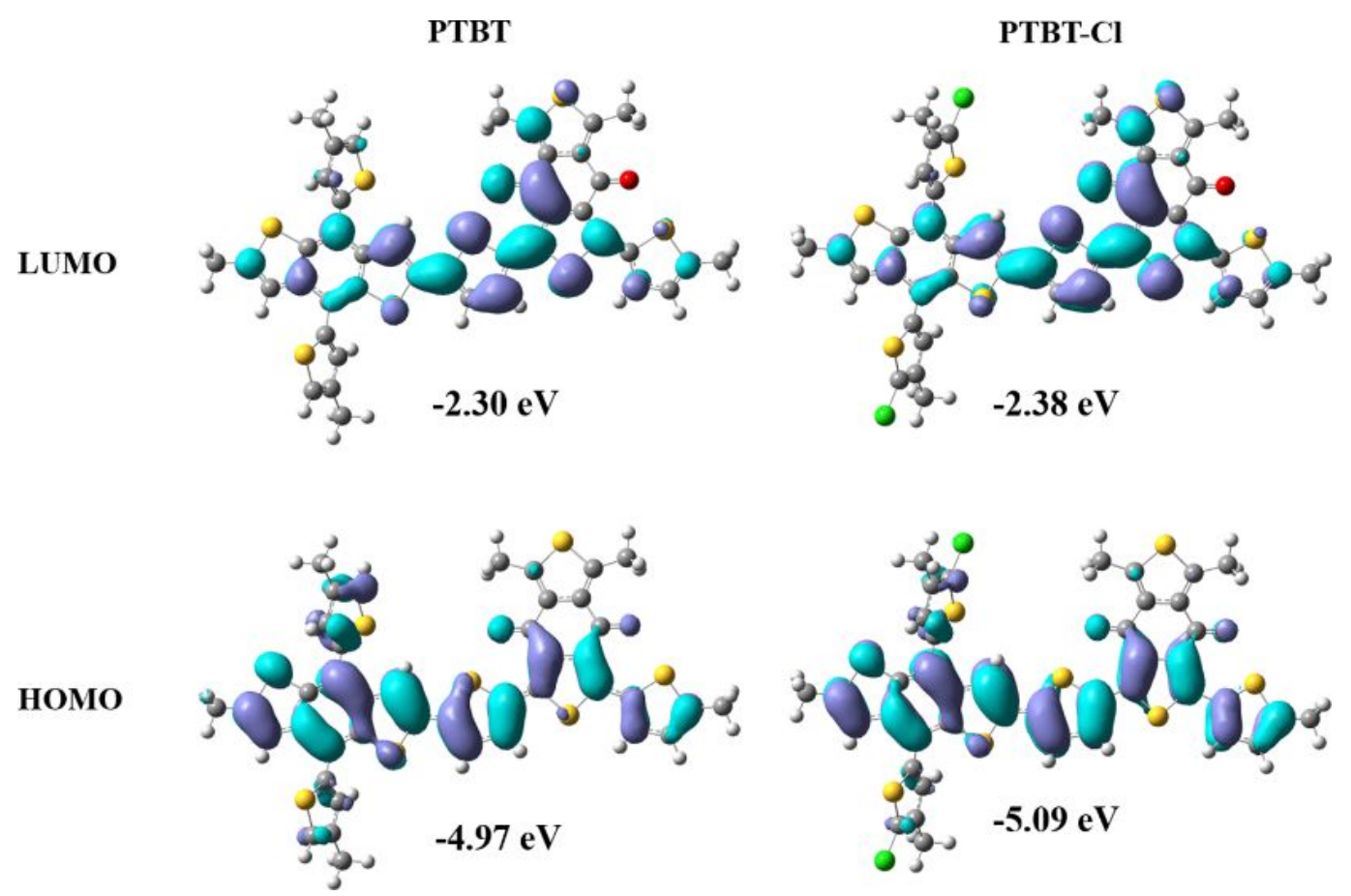

Figure S3. Optimized molecular backbone conformations of polymers using DFT calculations at the B3LYP/6-31g*(d, p) level: the HOMO and LUMO electron distributions based on one repeat unit of PTBT and PTBT-Cl. 


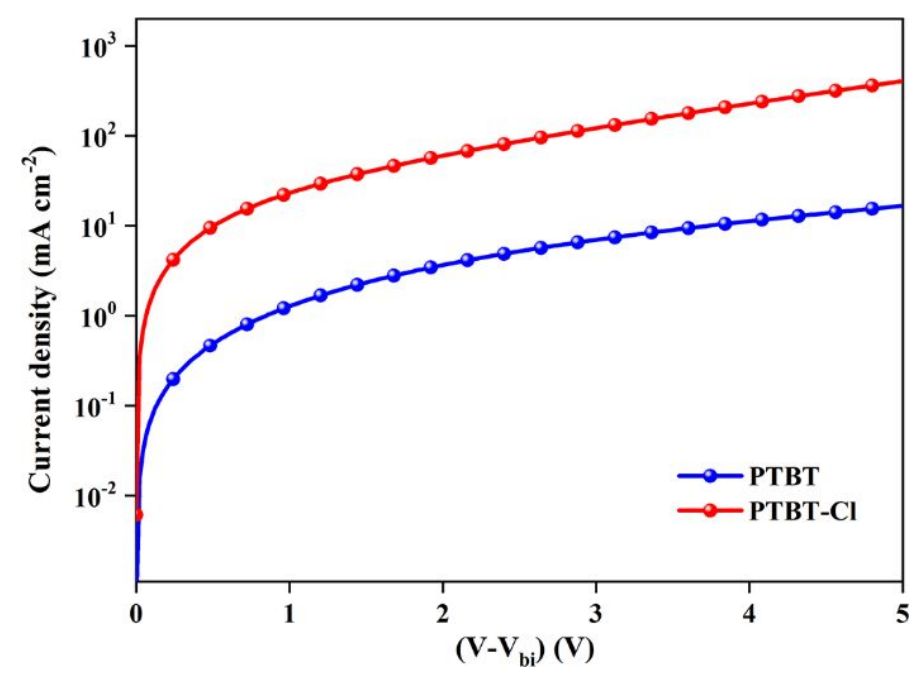

Figure S4. The curves of the hole-only devices based on polymer:Y6.

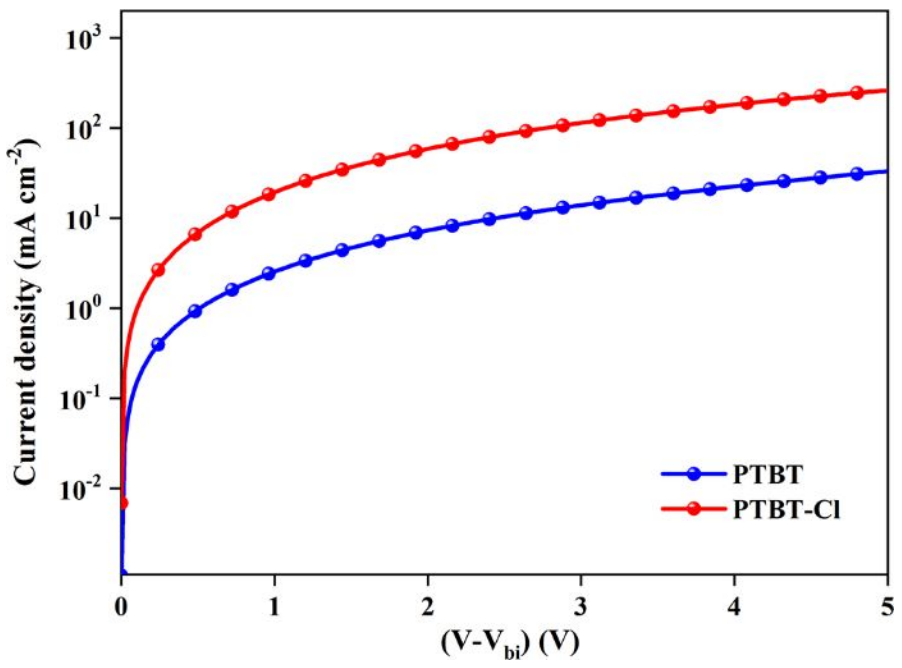

Figure S5. The curves of the electron-only devices based on polymer:Y6. 


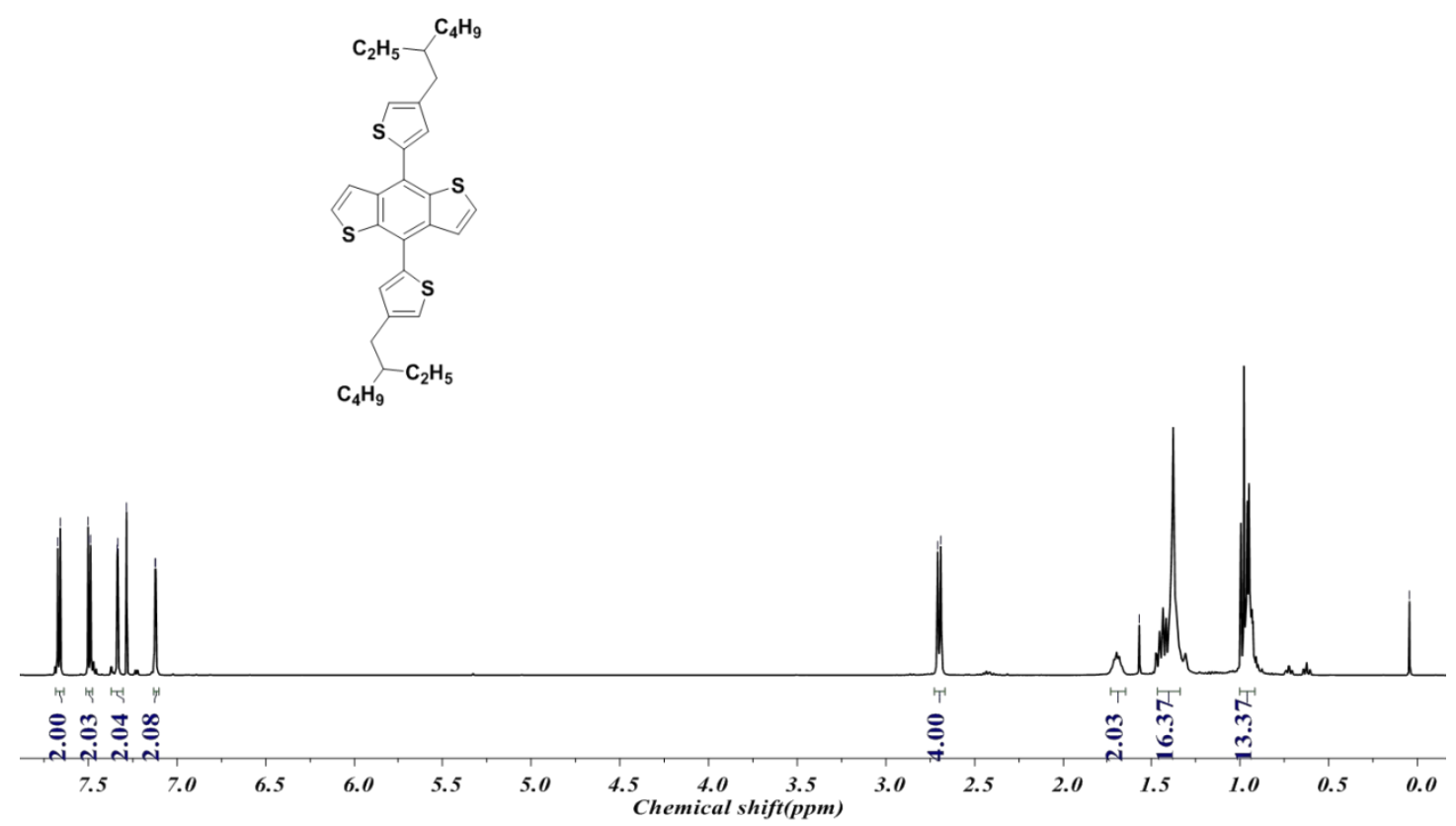

Figure S6. ${ }^{1} \mathrm{H}$ NMR spectrum of compound (1).
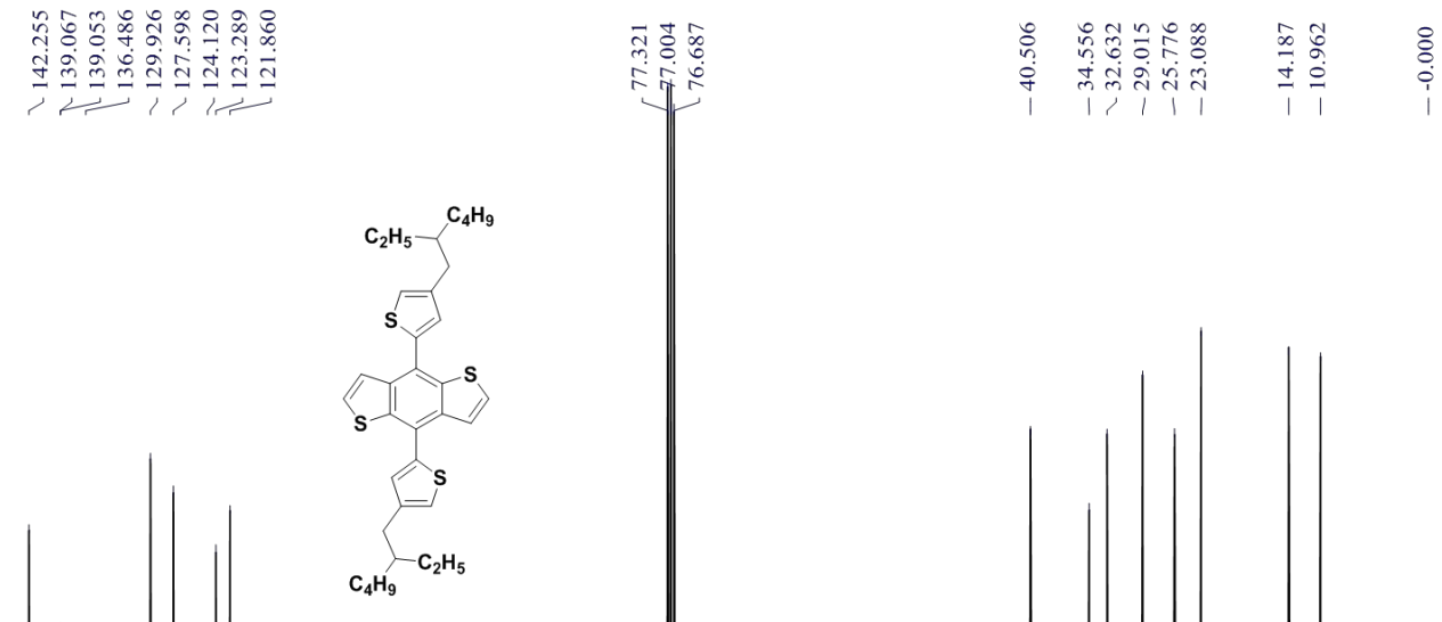

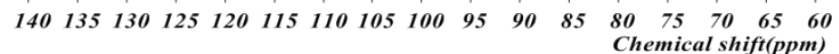

Figure S7. ${ }^{13} \mathrm{C}$ NMR spectrum of compound (1). 


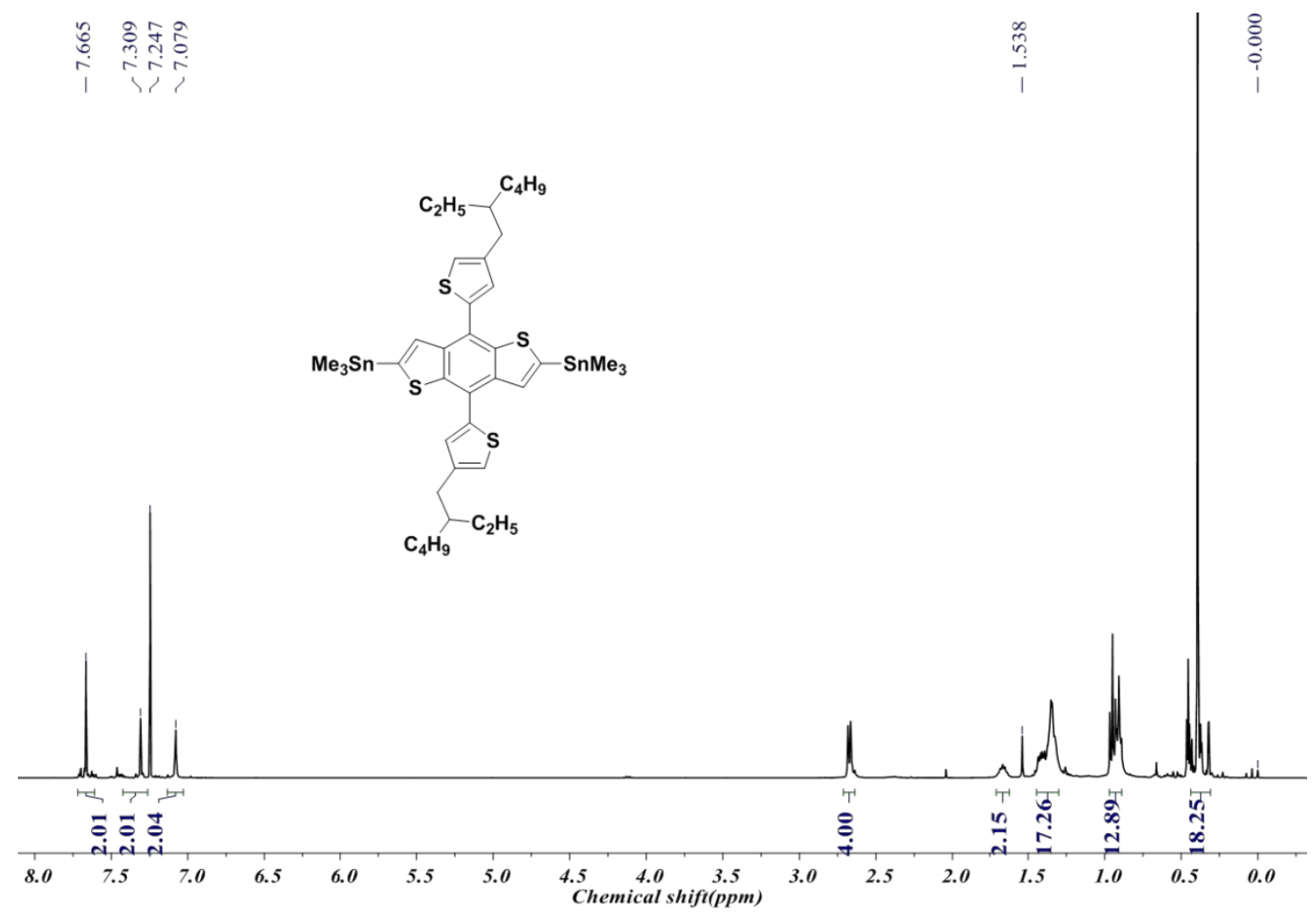

Figure S8. ${ }^{1} \mathrm{H}$ NMR spectrum of compound M1.

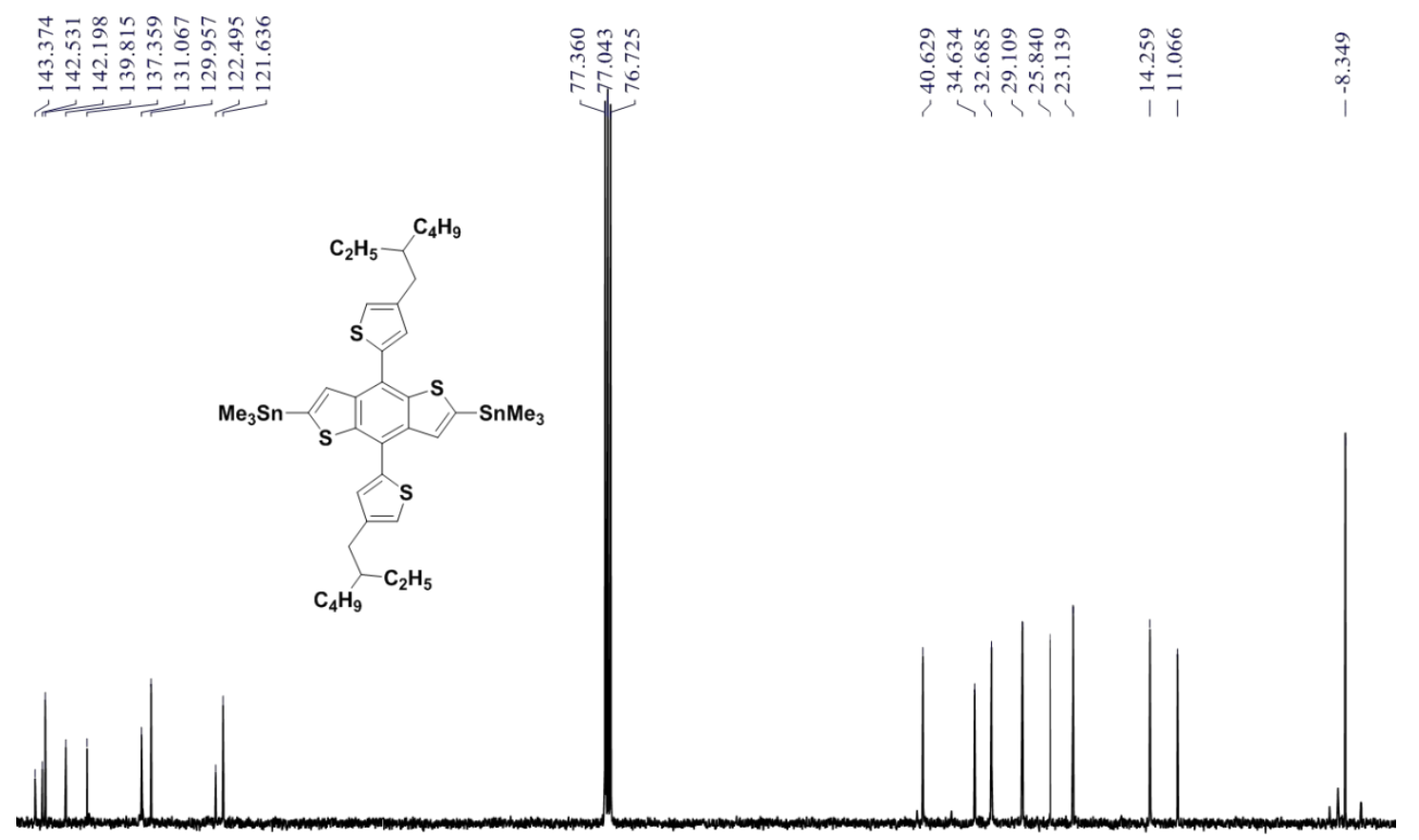

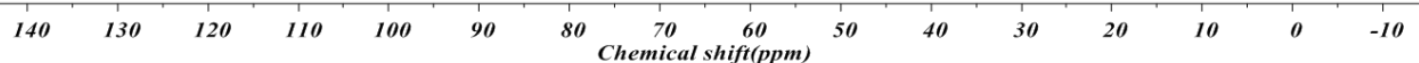

Figure S9. ${ }^{13} \mathrm{C}$ NMR spectrum of compound M1. 


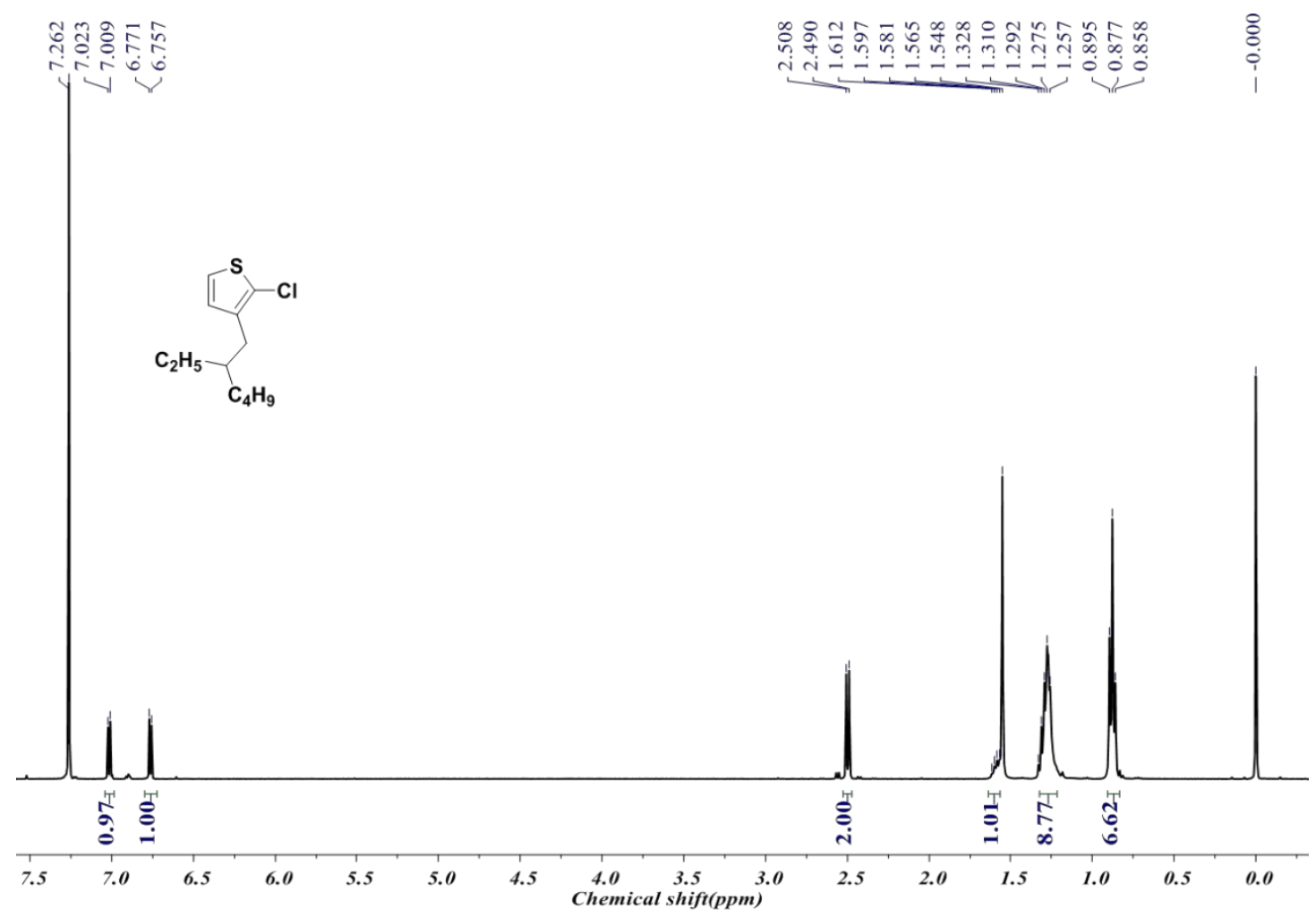

Figure S10. ${ }^{1} \mathrm{H}$ NMR spectrum of compound (2).
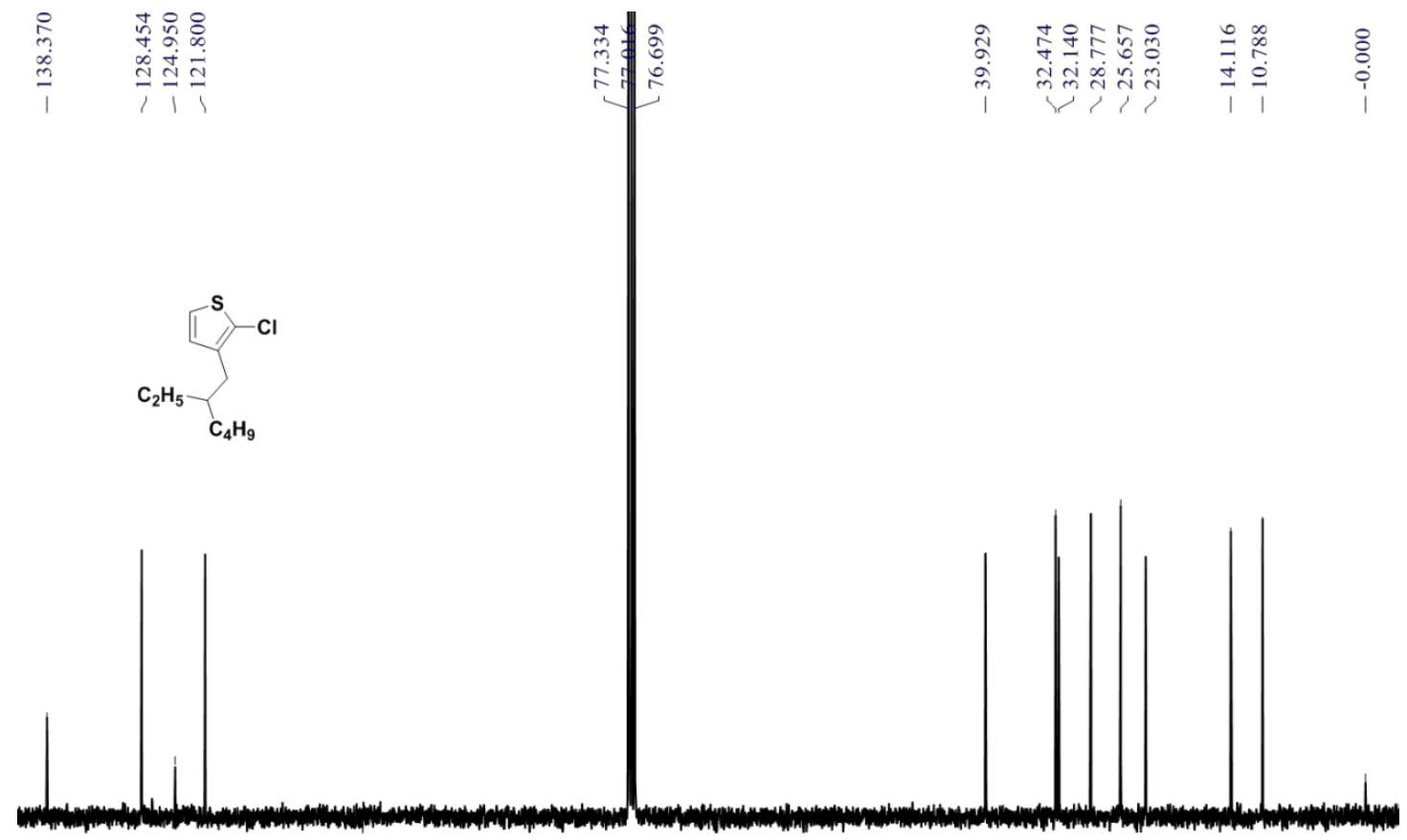

$\begin{array}{llllllllllllllllllllllllllllllll}140 & 135 & 130 & 125 & 120 & 115 & 110 & 105 & 100 & 95 & 90 & 85 & 80 & 75 & 70 & 65 & 60 & 55 & 50 & 45 & 40 & 35 & 30 & 25 & 20 & 15 & 10 & 5 & 0\end{array}$

Figure S11. ${ }^{13} \mathrm{C}$ NMR spectrum of compound (2). 

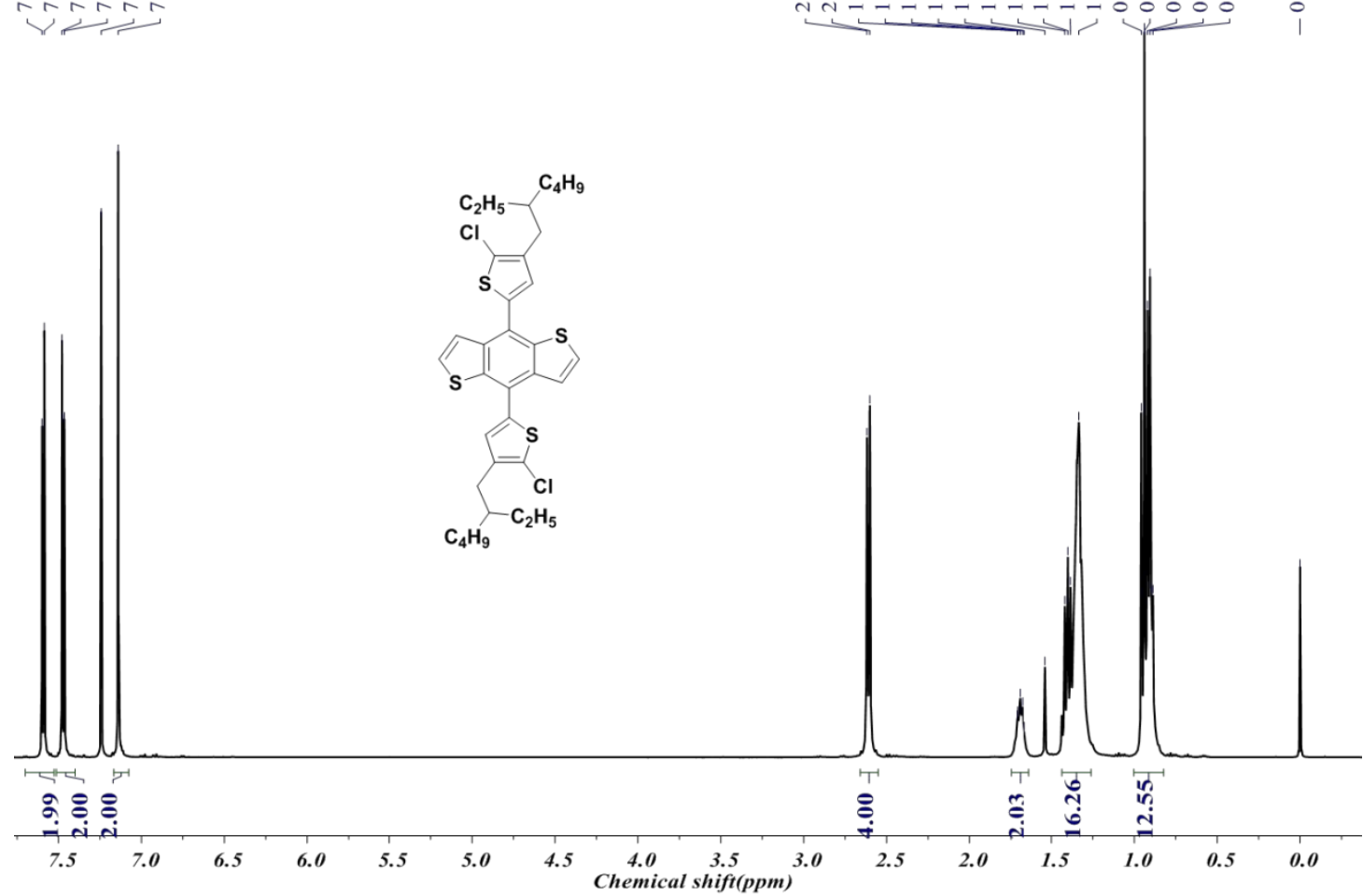

Figure S12. ${ }^{1} \mathrm{H}$ NMR spectrum of compound (3).
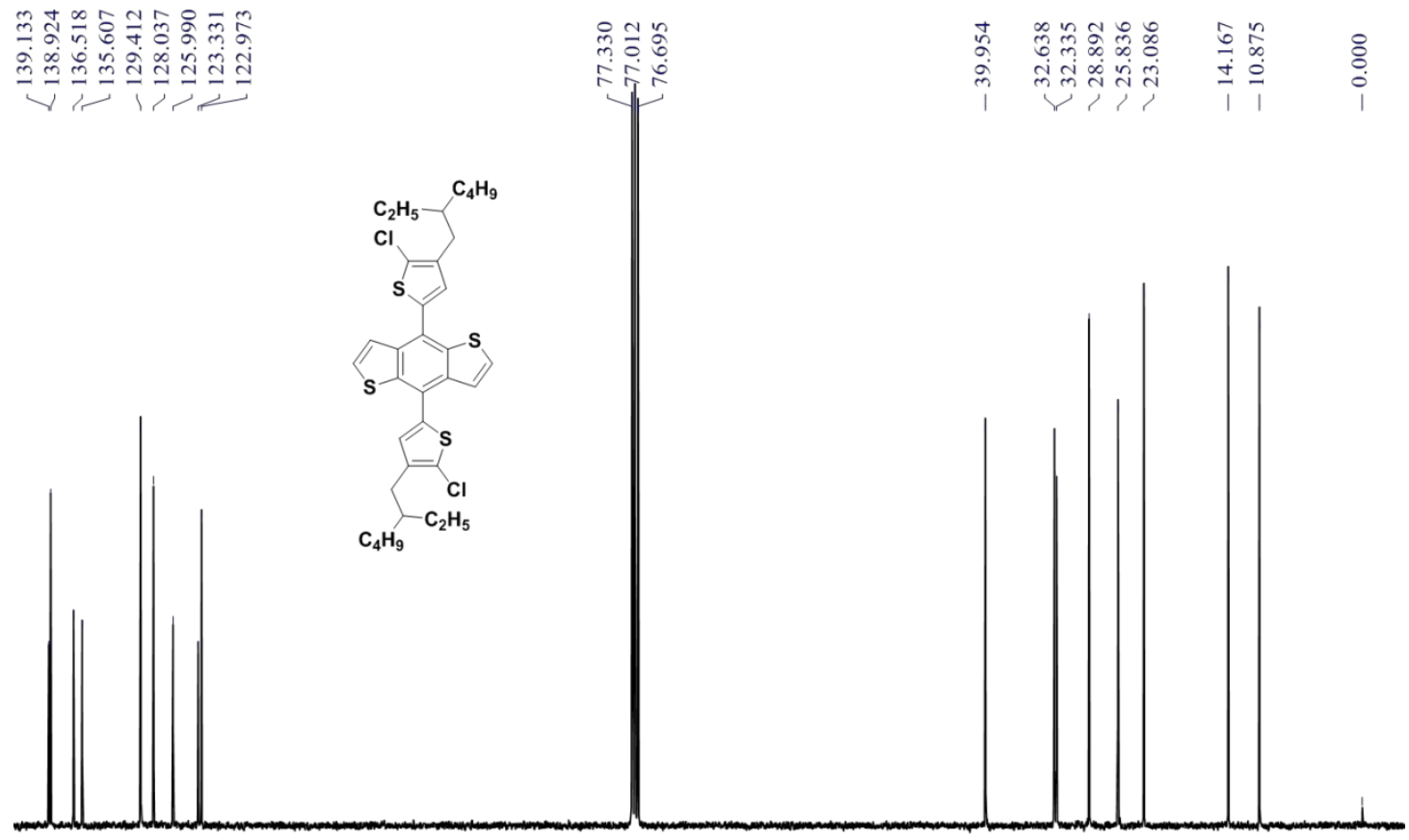

$\begin{array}{llllllllllllllllllllllllllllllllllllllll}140 & 135 & 130 & 125 & 120 & 115 & 110 & 105 & 100 & 95 & 90 & 85 & 80 & 75 & 70 & 65 & 60 & 55 & 50 & 45 & 40 & 35 & 30 & 25 & 20 & 15 & 10 & 5 & 0\end{array}$

Figure S13. ${ }^{13} \mathrm{C}$ NMR spectrum of compound (3). 


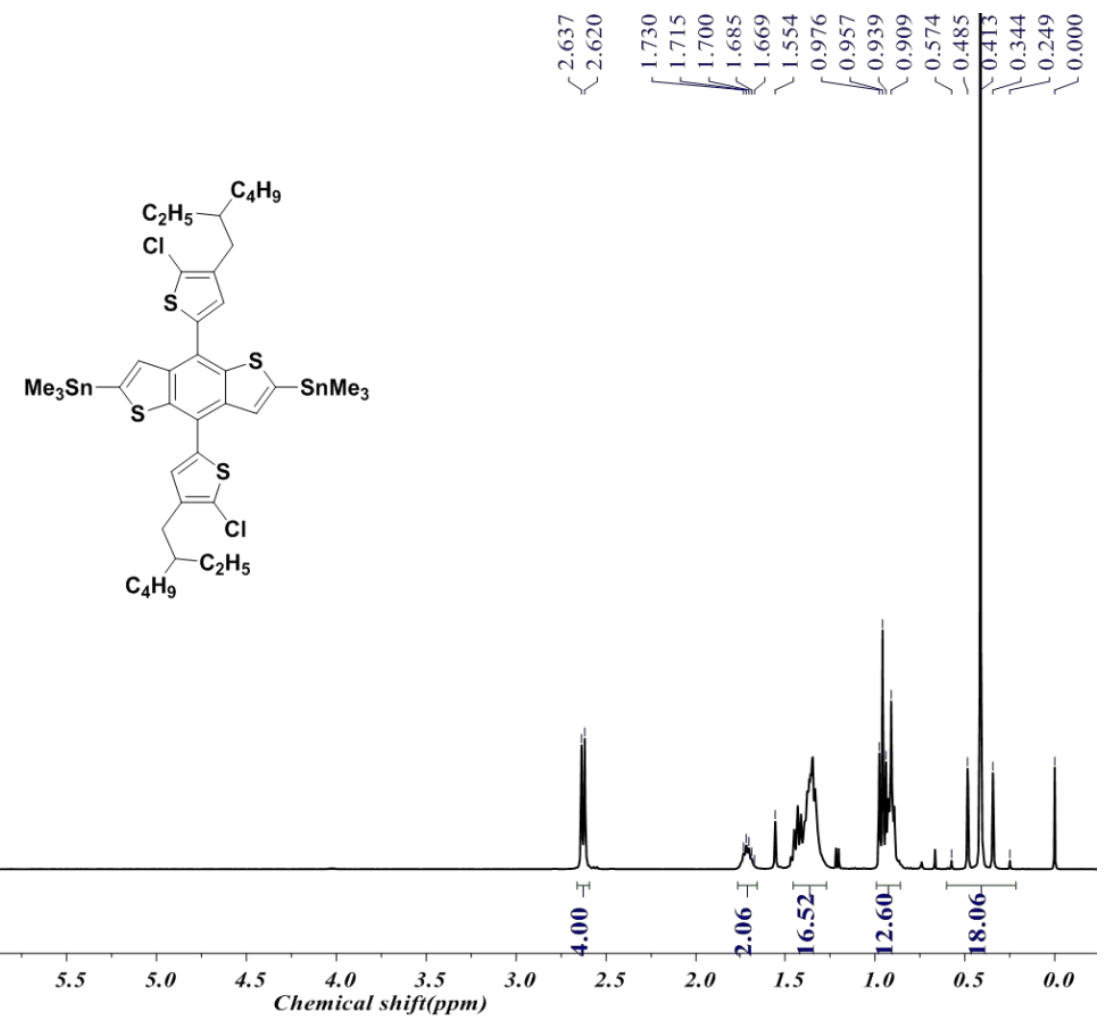

Figure S14. ${ }^{1} \mathrm{H}$ NMR spectrum of compound M2.
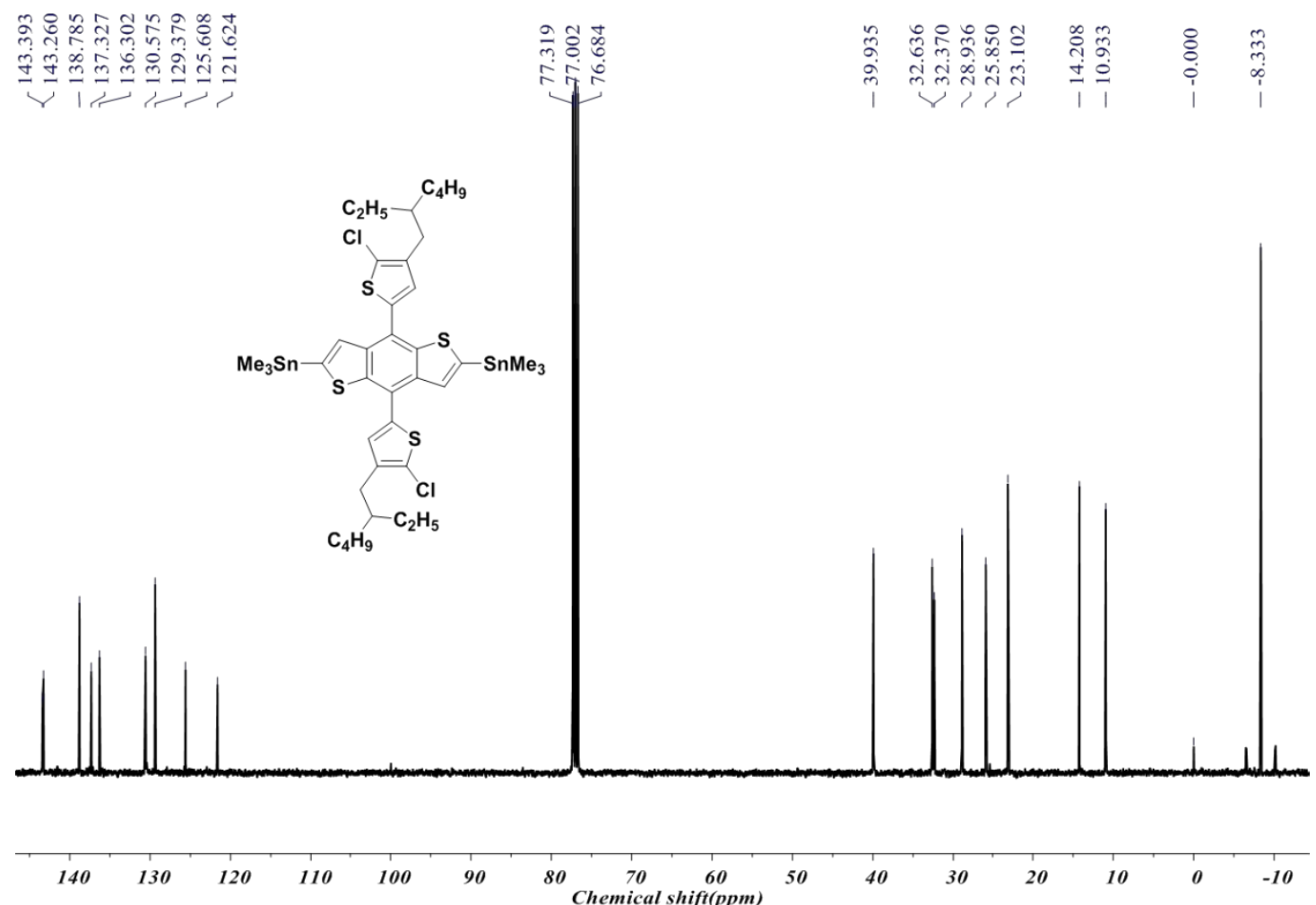

Figure S15. ${ }^{13} \mathrm{C}$ NMR spectrum of compound M2. 


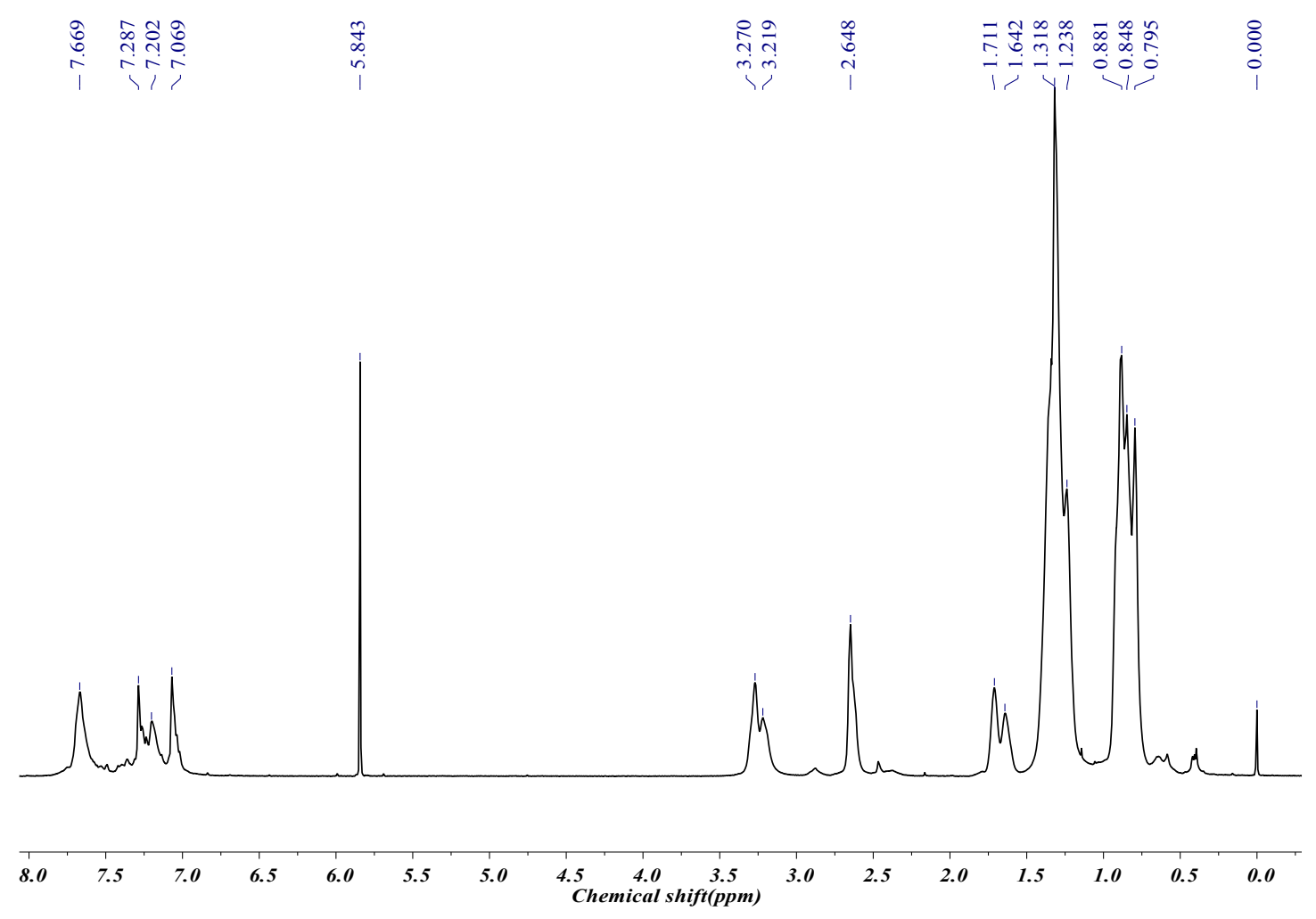

Figure S16. ${ }^{1} \mathrm{H}$ NMR spectrum of polymer PTBT.

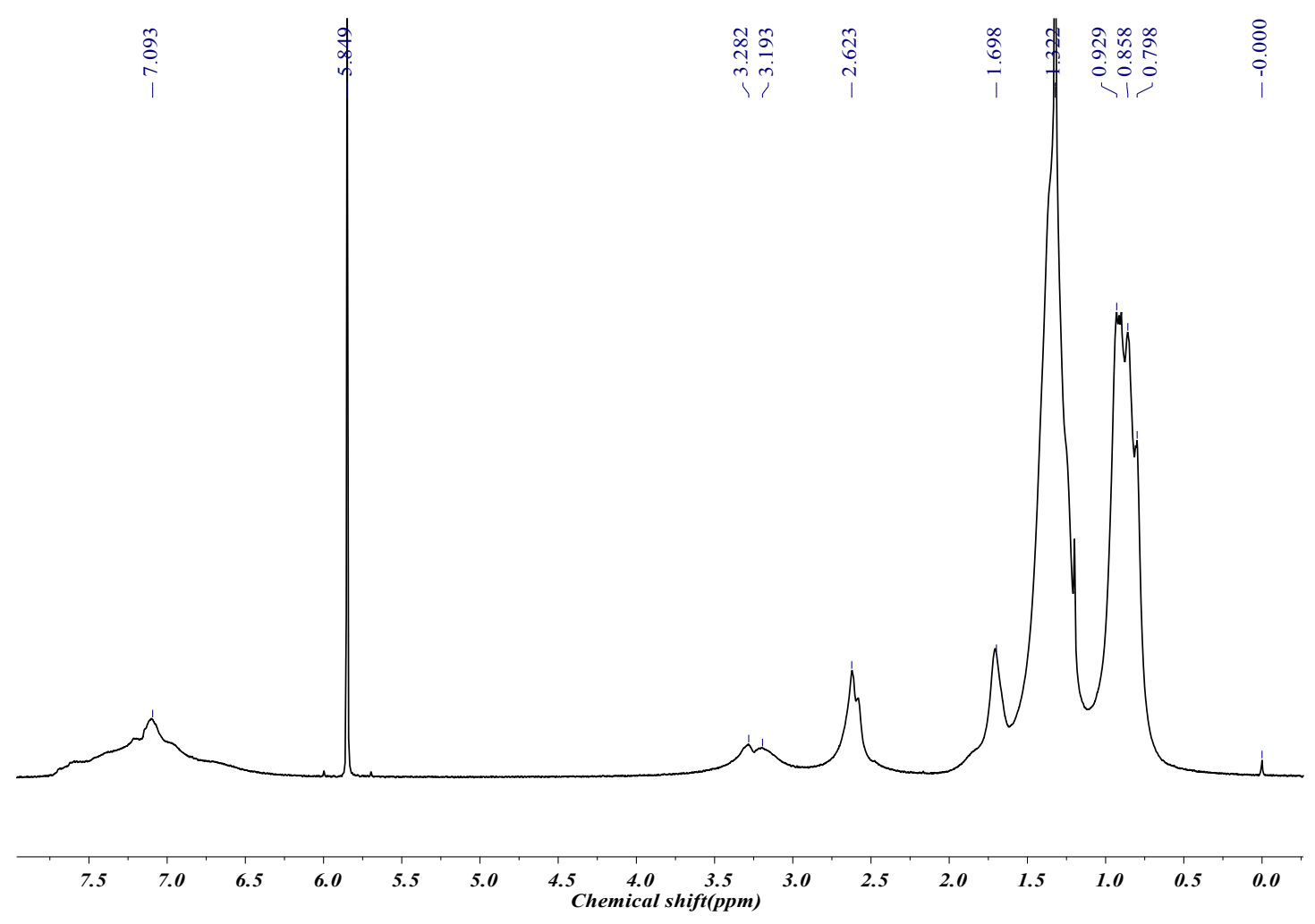

Figure S17. ${ }^{1} \mathrm{H}$ NMR spectrum of polymer PTBT-Cl. 


\section{MW Averages}

Mp: 54196

Mn: 31015

Mv: 59140

Mw: 64909

$\mathrm{Mz}: 111301$

$\mathrm{Mz}+1: 165289$

PD: 2.0928

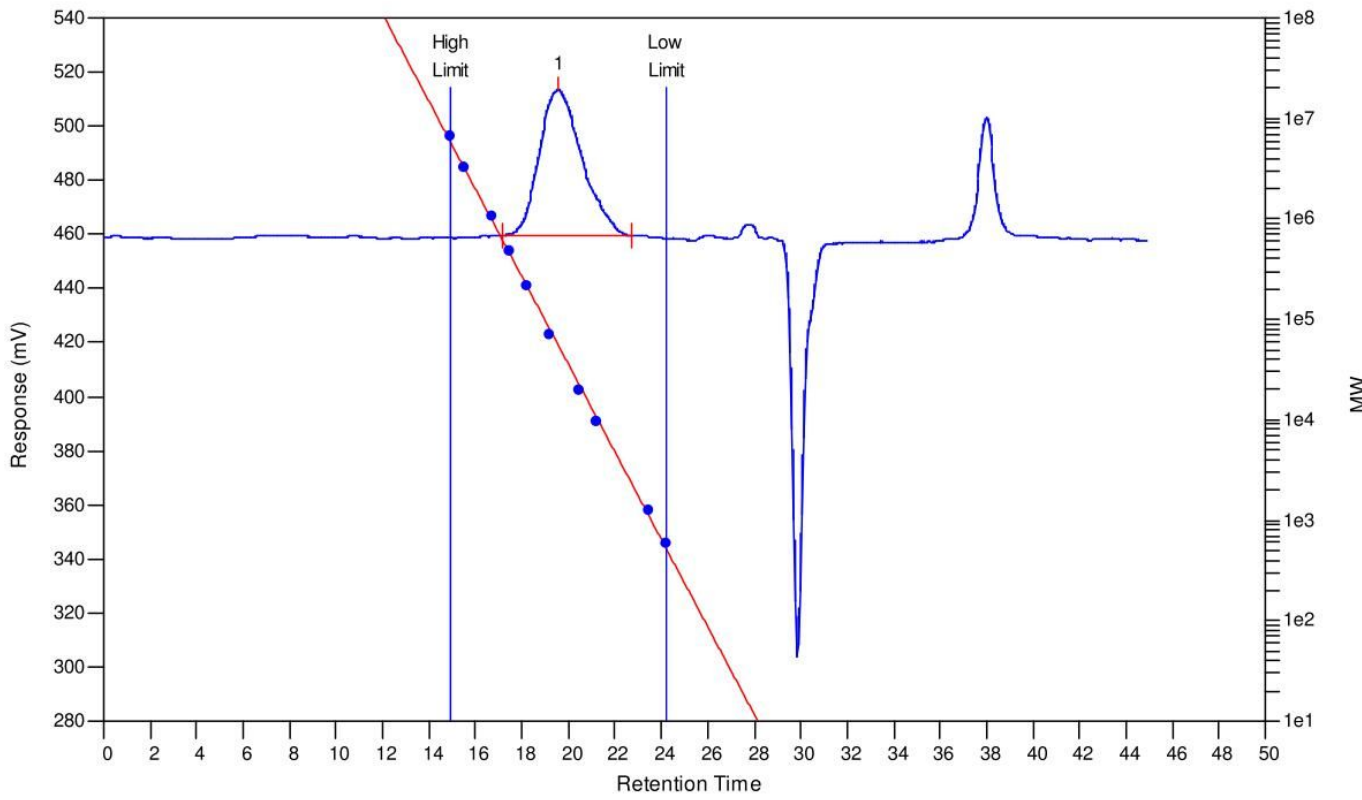

Figure S18. GPC data of polymer PTBT.

\section{MW Averages}

$\begin{array}{llll}\text { Mp: } 74474 & M n: 38623 & \text { Mv: } 76708 & \text { Mw: } 84704 \\ M z: 149630 & M z+1: 224285 & \text { PD: } 2.1931 & \end{array}$

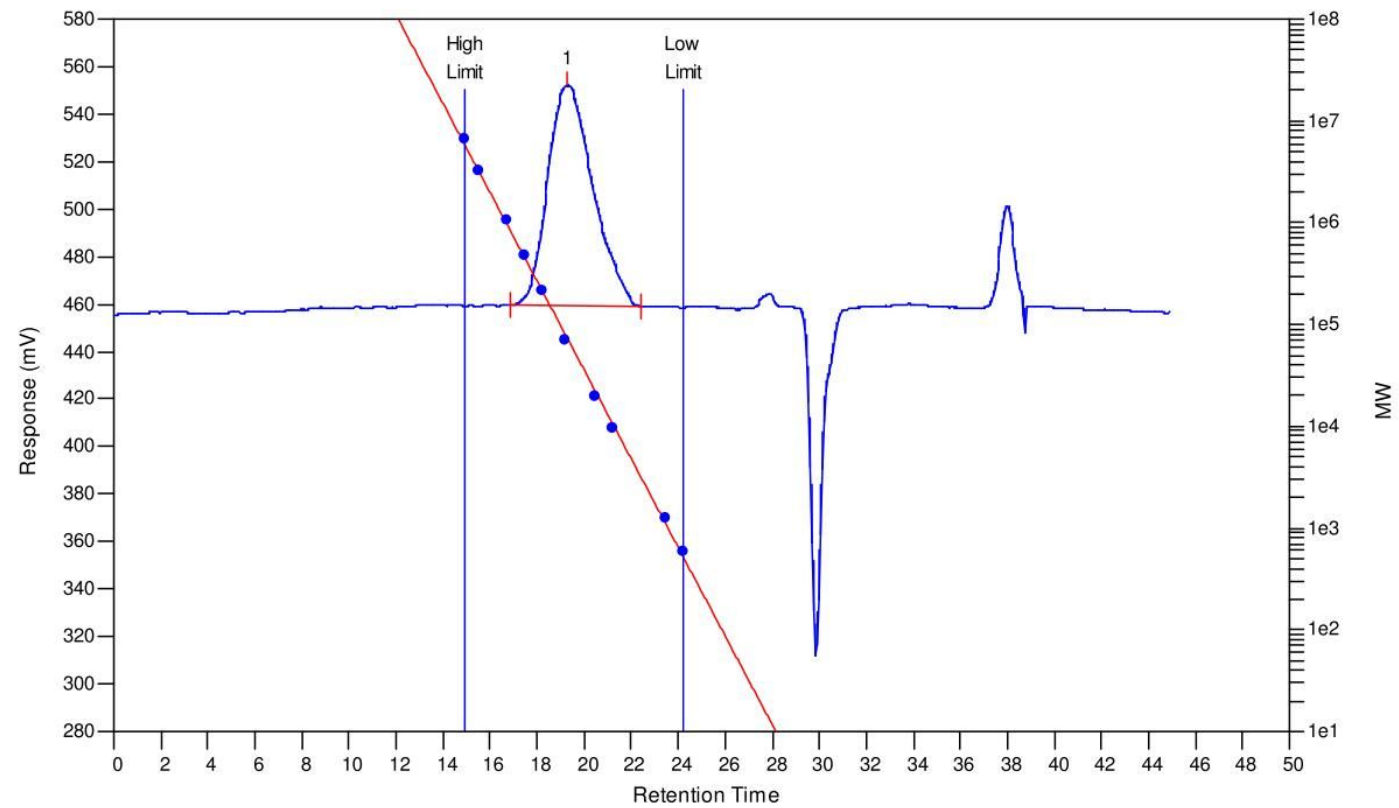

Figure S19. GPC data of polymer PTBT-Cl. 